\title{
Conception rate of lactating cows and heifers (Bos taurus X Bos indicus) for sexed and conventional semen in artificial insemination*
}

\author{
Taxa de concepção de vacas lactantes e novilhas \\ (Bos taurus $X$ Bos indicus) com o uso de sêmen sexado e \\ convencional na inseminação artificial
}

\author{
Anelise Ribeiro Peres, ${ }^{* *}$ Aderson Maurício Ifran, ${ }^{* *}$ Marina Ragagnin de Lima, ${ }^{* *}$ Guilherme Fazan Rossi, ${ }^{* *}$ \\ Rafael Rodrigues Corrêa, ${ }^{* * *}$ Joaquim Mansano Garcia**
}

\begin{abstract}
The objective of this study was to evaluate the conception rate of crossbred heifers $(n=50)$ and cows $(n=50)$ inseminated with sexed and conventional semen between 18 and 24 hours after estrous detection. The synchronization protocol of the estrous cycle started on day zero (D0) by inserting the intravaginal device with $1 \mathrm{~g}$ progesterone (Sincrogest® Ourofino, Brazil) and injecting 2 mg of

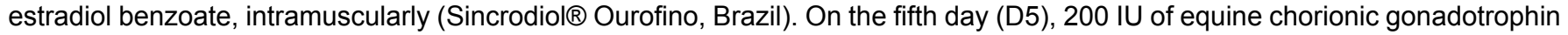
was injected intramuscularly (Folligon $®$, Intervet, Brazil). On the eighth day (D8), after removing the progesterone device, 500 $\mathrm{g}$ of sodium cloprostenol was injected intramuscularly (Sincrocio $\AA$, Ourofino, Brazil). After that, the animals were checked for estrus 3 times daily, and inseminated 18 to 24 hours after estrus detection. Pregnancy diagnosis was performed 30 to 40 days after insemination. Conception rate did not differ $(P>0.05)$ according to animal category, but was higher for conventional semen compared to sexed semen when evaluating the total of animals and lactating cows $(P<0.05)$. Artificial insemination of heifers with sexed semen 18 to 24 hours after estrus detection was effective, however, conventional semen was more efficient in lactating cows.
\end{abstract}

Keywords: bovine, spermatozoids, heat.

\section{Resumo}

Considerando os benefícios do uso de sêmen sexado e também os danos causados pelo processo de separação dos espermatozoides, o objetivo do presente estudo foi avaliar a taxa de concepção de novilhas $(n=50)$ e vacas $(n=50)$ mestiças inseminadas com sêmen sexado e convencional após 18 a 24 horas a observação do cio. O protocolo de sincronização do ciclo estral consistiu em inserção de dispositivo intravaginal com $1 \mathrm{~g}$ de progesterona (Sincrogest $囚$ Ourofino, Brasil) e aplicação intramuscular de $2 \mathrm{mg}$ de benzoato de estradiol (Sincrodiol $($ Ourofino, Brasil) no dia zero (D0). No quinto dia (D5), foi realizada uma aplicação intramuscular de 200Ul de gonadotrofina coriônica equina (Folligon®, Intervet, Brasil). No oitavo dia (D8), o dispositivo de progesterona foi retirado, e aplicado por via intramuscular $500 \mu \mathrm{g}$ de cloprostenol sódico (Sincrocio $\AA$, Ourofino, Brasil). A partir deste momento, o estro foi observado 3 vezes ao dia e os animais foram inseminados 18 a 24 após a detecção do cio. O diagnóstico de gestação foi realizado 30 a 40 dias após a inseminação. Não foi observada diferença na taxa de concepção de acordo com a categoria animal $(P>0,05)$, entretanto, animais inseminados com sêmen convencional apresentaram melhor taxa de concepção do que com sêmen sexado quando se avaliou o total de animais e vacas lactantes $(P<0,05)$. A inseminação artificial de novilhas com sêmen sexado 18 a 24 horas após detecção de estro mostrou-se eficaz, entretanto, para vacas lactantes não foi observada a mesma eficiência ao se comparar com o sêmen convencional.

Palavras-chave: bovinos, espermatozoides, cio.

\section{Introduction}

The use of sexed semen can bring several benefits to animal production (Vries et al., 2008). It can increase the effectiveness of progeny testing programs after artificial insemination (AI), resulting in higher number of births of the desired sex. Using $\mathrm{X}$-sexed semen to breed heifers substantially reduces the incidence of calving problems such as dystocia. An additional benefit of using sexed semen is the biosecurity of the farm; to expand the herd, producers acquire animal in auctions, from cattle dealers or other farmers, which may expose the herd to new pathogens, increasing the discard rate due to diseases. With the use of sexed semen, producers can expand from their own herd due to the increasing birth rate of animals with the desired sex (Weigel, 2004).

Sperm cells are sorted by flow cytometry, which is a reliable method, but still slow compared to the semen requirements of

\footnotetext{
*Recebido em 14 de agosto de 2016 e aceito em 13 de outubro de 2016.

**Universidade Estadual Paulista "Júlio de mesquita Filho" - FCAV/UNESP- Departamento de Medicina Veterinária Preventiva e Reprodução Animal Jaboticabal, SP, Brasil

${ }^{* * *}$ Ourofino Agronegócio, Cravinhos, SP, Brasil

Corresponding autor: Anelise Ribeiro Peres - ane.medvet@hotmail.com
} 
commercial dairy herds (Weigel, 2004; Garner and Seidel, 2008). Given the challenges associated with sperm separation speed, the number of sexed sperm is generally low, about two million sperms per straw, which is considerably less than twenty million sperms per straw for conventional semen (Olynk and Wolf, 2007; Mallory et al., 2013).

The separation process also damages sperm cells, affecting their fertilization capacity (Vazquez et al., 2008; Carvalho et al., 2009). Physical and chemical stress during the sorting process can damage the sperm and accelerating the process of capacitation and acrosome reaction (Mocé et al., 2006). Hence, the combined effects of low sperm numbers and reduced semen quality has resulted in lower conception rate after Al compared to conventional semen (Anderson et al., 2006; Seidel Júnior and Schenk, 2008; Sales et al., 2011; Mallory et al., 2013; Sá Filho et al., 2013).

Considering the benefits of sexed semen, this study devised a strategy to optimize the efficient use of sexed semen in artificial insemination of crossbred cows and heifers. That is, since the sperm sorting process reduces its lifetime, artificial insemination was performed in the nearest period of ovulation. Thus, the aim of this study was to evaluate the conception rate of crossbred heifers and cows inseminated with sexed and conventional semen between 18 and 24 hours after estrus observation.

\section{Material and methods}

Animal care procedures throughout the study followed protocols approved by the Ethics Committee for Animal Use (ECAU) of Universidade Estadual Paulista - UNESP/FCAV, under $n^{\circ} 016926 / 13$.

The experiment was conducted in dairy farms located in the northwest region of São Paulo. Fifty crossbred Gir $\times$ Holstein (Bos taurus $x$ Bos indicus) lactating cows (average 16 liters/day) raised in pasture system with up to three lactations (all over 60 days postpartum) and 50 crossbred Gir $\times$ Holstein pubescent heifers (Bos taurus $x$ Bos indicus ), were used $(n=100)$. The body condition scores of the animals ranged from 3 to 3.5 .

All animals were grazed on Tifton 85 (Cynodon spp.) and mombaça (Panicum maximum), and salt and water were provided ad libitum. The lactating cows, in addition to pasture, were fed concentrate with $23 \%$ crude protein $(\mathrm{CP})$ at a ratio of $1 \mathrm{~kg}$ of feed per $3 \mathrm{~kg}$ of milk.

The synchronization protocol of the estrus cycle started on a random day of the cycle. First day (D0) of protocol was started by inserting an intravaginal device with $1 \mathrm{~g}$ of progesterone (P4) (Sincrogest $\AA$ Ourofino, Brazil) and injecting $2 \mathrm{mg}$ of estradiol benzoate, intramuscularly (EB) (Sincrodiol $\circledast$ Ourofino, Brazil). On the fifth day (D5), 200 IU equine chorionic gonadotropin (eCG) was injected, intramuscularly (Folligon $\AA$, Intervet, Brazil). On the eighth day (D8), the progesterone device was removed, and 500 $\mathrm{g}$ of sodium cloprostenol (PGF2 $\alpha$ ) (Sincrocio®, Ourofino, Brazil) was injected intramuscularly. Starting on day 9 , cows and heifers were checked for estrus 3 times a day (06:00h/12:00/18:00h) and after estrus was detected, the animals were inseminated between 18 and 24 hours, as illustrated in Figure 1. The animal was considered in estrus when a cow or heifer repeatedly stands and accepts mounting by one of her herd mates.

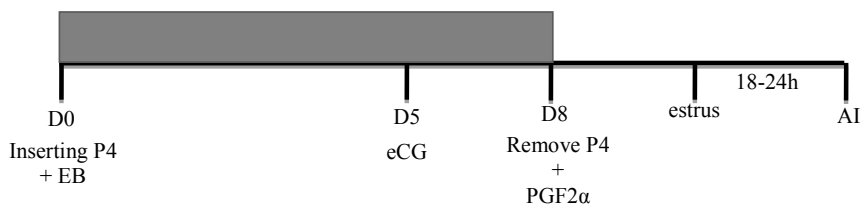

Figure 1: Synchronization protocol of the estrous cycle of heifers and cows for artificial insemination with conventional and sexed semen, between 18 and 24 hours after the observation of estrus

Conception rates were determined for the two animal categories and conventional and sexed semen. Of the total, 25 cows and 25 heifers were inseminated with conventional semen and 25 cows and 25 heifers were inseminated with sexed semen. The inseminations were distributed interchangeably between categories, types of semen and farms; one cow was inseminated with sexed semen and the other with conventional semen, likewise with heifers of a farm and the same process was repeated in the other farms. The inseminations were carried out from November 2013 to January 2014.

For $\mathrm{Al}$, semen straws were thawed at $36^{\circ} \mathrm{C}$ for 30 seconds and placed in the insemination gun. All inseminations were performed by the same Al technitian. Semen from the same Gir bull and the same batch was purchased from an insemination center and used in both artificial inseminations with conventional and sexed semen.

Pregnancy was confirmed 30 to 40 days after Al using an Aloka SSD-900 V ultrasound device (Corometrics Medical Sistems Inc., Wallingford, CT, USA) and a trans-rectal linear transducer UST- 7, $5 \mathrm{MHz}$.

The conception rates were analyzed by the chi-square test $\left(X^{2}\right)$ for the two categories and two techniques, at $p<0.05$ significance. Analyses were performed using the "Statistical Analysis System" (SAS) software.

\section{Results and discussion}

The conception rates of artificial insemination with conventional semen were significantly higher compared to sexed semen for heifers and cows evaluated together (Table 1) and for cows evaluated separately (Table 2). Several authors also observed a statistical difference when comparing sexed and conventional semen, for both estrus detection (Bodmer et al., 2005; Anderson et al., 2006; Sá Filho et al., 2013) and fixed-time artificial insemination (FTAI) (Sales et al., 2011; Mallory et al., 2013; Sá Filho et al., 2013). However, the use of sexed semen is recommended to reach best results after estrus detection (Mallory et al., 2013).

Table 1: Conception rate results for heifers and cows (Gir $\times$ Holstein) evaluated together, after artificial insemination with conventional and sexed semen between 18 and 24 hours after estrous detection

\begin{tabular}{lllll}
\hline Semen & $\mathrm{N}$ total $^{(1)}$ & $\mathrm{N}$ pregnant $(\%)^{(2)}$ & Valor $^{X^{2}}$ & $\mathrm{p}$ \\
\hline Conventional & 50 & $35(70 \%)$ & 5,0021 & 0,0253 \\
Sexed & 50 & $24(48 \%)$ & & \\
\hline
\end{tabular}

Significant different by $\mathrm{X}^{2}$ test, at $\mathrm{P}<0.05$

${ }^{(1)} \mathrm{N}$ total $=$ tota

${ }^{(2)} \mathrm{N}$ pregnant $=$ number of the pregnant animals 
Table 2: Conception rate results for cows (Gir $\times$ Holstein) after artificial insemination with conventional and sexed semen between 18 and 24 hours after the observation of estrus

\begin{tabular}{lllll}
\hline Semen & $\mathrm{N}$ total $^{(1)}$ & $\mathrm{N}$ pregnant $(\%)^{(2)}$ & ${\text { Valor } \mathrm{X}^{2}}$ & $\mathrm{p}$ \\
\hline Conventional & 25 & $18(72 \%)$ & 4,0230 & 0,0449 \\
Sexed & 25 & $11(44 \%)$ & & \\
\hline
\end{tabular}

Significant different by $\mathrm{X}^{2}$ test, at $\mathrm{P}<0.05$

${ }^{(1)} \mathrm{N}$ total $=$ total number of animals

${ }^{(2)} \mathrm{N}$ pregnant $=$ number of the pregnant animals

The physical and chemical stress during the sorting process can damage the sperm and accelerating the process of capacitation and acrosome reaction (Mocé et al., 2006).

According to Sá Filho et al. (2013), crossbred cows (Gir × Holstein) inseminated $12 \mathrm{~h}$ after estrus detection with sexed semen presented higher conception rate per insemination (32\%) than cows inseminated after Timed-AI (22\%). In addition, Mallory et al. (2013) demonstrated that the expression of estrus before timed-Al did not affect conception rate for insemination with conventional semen $(70 \%$ versus $67 \%)$ while conception rates for sexed semen was higher for heifers detected in estrus ( $46 \%$ versus $26 \%$ ).

Therefore, to perform Al close to ovulation period, or delaying insemination (as accomplished in this study) may improve the fertility of sex-sorted sperm. In his sense, Jersey heifers were inseminated with sex-sorted sperm, and the conception rate was higher for Al performed between 16 and $24 \mathrm{~h} \mathrm{(54 \% )} \mathrm{vs} 12$ and 16 hours (37.7\%) after the onset of estrus (Sá Filho et al., 2010).

Additionally, Bombadelli et al. (2016) inseminated lactating Jersey cows with sexed semen to evaluate five intervals between estrus observation and artificial insemination (less than 4 hours, 4-12 hours, 13-21 hours, 23-41 hours and more than 41 hours). These authors reported that the insemination performed in the 23 to 41 -hour interval presented best conception rate (48.9\%). The 13 to 22-hour interval was also a good result demonstrated by the authors ( $44.3 \%$ conception rate), which is similar to the obtained in this study for the 18-24 hours interval.

However, the conception rates for heifers artificially inseminated with conventional and sexed semen were not significantly different (Table 3). Moreover, for both semen types, dairy heifers have higher fertility rates than lactating cows (Garner and Seidel, 2008; Seidel Júnior and Schenk, 2008). Thus, the sexed semen is recommended for use on heifers since they are more fertile than older cows (Mallory et al., 2013).

Table 3: Conception rate results for heifers (Gir $\times$ Holstein) after artificial insemination with conventional and sexed semen between 18 and 24 hours after the observation of estrus

\begin{tabular}{lcccc}
\hline Semen & $N$ total $^{(1)}$ & $\mathrm{N}$ pregnant $(\%)^{(2)}$ & Valor $\mathrm{X}^{2}$ & $\mathrm{p}$ \\
\hline Conventional & 25 & $17(68 \%)$ & 1,3333 & 0,2482 \\
Sexed & 25 & $13(52 \%)$ & & \\
\hline
\end{tabular}

Significant different by $\mathrm{X}^{2}$ test, at $\mathrm{P}<0.05$

${ }^{(1)} \mathrm{N}$ total $=$ total number of animals

${ }^{(2)} \mathrm{N}$ pregnant $=$ number of the pregnant animals
Regarding the animal category, the conception rates of cows and heifers artificially inseminated with conventional and sexed semen were not significantly different in this study (Tables 4 , 5 and 6). Dominguez et al. (2011) did not observe statistically significant differences between Nellore cows and heifers inseminated with sexed semen. However, there are few studies comparing the effect of animal category on conception rates separately.

Table 4: Conception rate results for heifers and cows (Gir $\times$ Holstein) after artificial insemination with conventional and sexed semen (evaluated together) between 18 and 24 hours after the observation of estrus

\begin{tabular}{ccccc}
\hline Category & $N$ total $^{(1)}$ & $\mathrm{N}$ pregnant $(\%)^{(2)}$ & ${\text { Valor } \mathrm{X}^{2}}$ & $\mathrm{p}$ \\
\hline Heifer & 50 & $30(60 \%)$ & 0,0413 & 0,8389 \\
Cow & 50 & $29(58 \%)$ & & \\
\hline
\end{tabular}

Significant different by $\mathrm{X}^{2}$ test, at $\mathrm{P}<0.05$

(1) $\mathrm{N}$ total $=$ total number of animals

${ }^{(2)} \mathrm{N}$ pregnant $=$ number of the pregnant animals

Table 5: Conception rate results for heifers and cows (Gir $\times$ Holstein) after artificial insemination with conventional sêmen between 18 and 24 hours after the observation of estrus

\begin{tabular}{ccccc}
\hline Category & $\mathrm{N} \mathrm{total}^{(1)}$ & $\mathrm{N}$ pregnant $(\%)^{(2)}$ & Valor $\mathrm{X}^{2}$ & $\mathrm{p}$ \\
\hline Heifer & 25 & $17(68 \%)$ & 0,0952 & 0,7576 \\
Cow & 25 & $18(72 \%)$ & & \\
\hline
\end{tabular}

Significant different by $X^{2}$ test, at $P<0.05$

(1) $\mathrm{N}$ total $=$ total number of animals

(2) $\mathrm{N}$ pregnant $=$ number of the pregnant animals

Table 6: Conception rate results for heifers and cows (Gir $\times$ Holstein) after artificial insemination with sexed semen between 18 and 24 hours after the observation of estrus

\begin{tabular}{ccccc}
\hline Category & $\mathrm{N}$ total $^{(1)}$ & $\mathrm{N}$ pregnant $(\%)^{(2)}$ & Valor $\mathrm{X}^{2}$ & $\mathrm{p}$ \\
\hline Heifer & 25 & $13(52 \%)$ & 0,3205 & 0,5713 \\
Cow & 25 & $11(44 \%)$ & & \\
\hline
\end{tabular}

Significant different by $\mathrm{X}^{2}$ test, at $\mathrm{P}<0.05$

${ }^{(1)} \mathrm{N}$ total $=$ total number of animals

${ }^{(2)} \mathrm{N}$ pregnant $=$ number of the pregnant animals

In this study, good conception rates were obtained using conventional semen compared to others, but crossbred animals have better fertility (Heins et al., 2006; Borges et al., 2009; Schaefer et al., 2011; Heins and Hansen, 2012). Several studies demonstrated that conception rates for Holstein cows are low even for conventional semen after Al (Anderson et al., 2006; Chebel et al., 2010; Dejarnette et al., 2010, Dejarnette et al., 2011). These results may be related to high milk production, which in turn increases the energy needs, and consequently, the metabolism, leading to metabolic disorders such as thermal stress, negative energy balance, and high metabolization of steroids. Thus, affecting negatively the reproduction rates of these animals (Sagsritavong et al., 2002; Rensis and 
Scaramuzzi, 2003; Chebel et al., 2004; Shehab-El-Deen et al., 2010; Walsh et al., 2011).

Furthermore, the conception rates for sexed semen were low even for crossbred animals, corroborating the results of other studies with other breeds, including beef cattle, which had low conception rates for insemination with sexed semen (Sales et al., 2011; Sá Filho et al., 2013). The conception rate for sexed semen insemination is between $60 \%$ and $90 \%$ lower than that observed for conventional semen (Dejarnette et al., 2009; Schenk et al., 2009; Dejarnette et al., 2010; Healy et al., 2013;) and the results of this study are within this range $(61.1 \%-76.4 \%)$.

Another important factor affecting conception rates of sexed semen is the individual bull fertility, which is a cause for inconsistent results of several studies (Sales et al., 2011). Semen

\section{References}

ANDERSON, M.; TAPONEN, J.; KOMMERI, M.; DAHLBOM, M. Pregnancy rates in lactating Holstein-Friesian cows after artificial insemination with sexed sperm. Reproduction in Domestic Animals, v.1, n. 1, p. 95-97, 2006.

BODMER, M.; JANETT, F.; HÄSSIG, M.; DAAS, N. D.; REICHERT, P.; THUN, R. Fertility in heifers and cows after low dose insemination with sex-sorted and non-sorted sperm under field conditions. Theriogenology, v. 64, n. 1, p.1647-1655, 2005.

BOMBARDELLI, G. D.; SOARES, H. F.; CHEBEL, R. C. Time of insemination relative to reaching activity threshold is associated with pregnancy risk when using sex-sorted semen for lactating Jersey cows. Theriogenology, v.85, n.1, p.533-539, 2016.

BORGES, A. M.; CARVALHO, B. C.; RUAS, J. R. M. Manejo reprodutivo da vaca mestiça: estado da arte. Revista Brasileira de Reprodução Animal, v. 1, n. 6, p. 157-162, 2009.

CARVALHO, J. O.; SARTORI, R.; LEMES, A. P.; MOURÃO, G. B.; DODE, M. A. N. I. Cinética de espermatozoides criopreservados de bovinos após sexagem por citometria de fluxo. Pesquisa Agropecuária Brasileira, v. 44, n. 10, p. 1346-1351, 2009.

CHEBEL, R. C.; GUAGNINI, F. S.; SANTOS, J. E. P.; FETROW, J. P.; LIMA, J. R. Sex-sorted semen for dairy heifers: effects on reproductive and lactational performances. Journal of Dairy Science, v. 93, n. 6, p. 2496-2507, 2010.

CHEBEL, R. C.; SANTOS, J. E. P.; REYNOLDS, J. P.; CERRI, R. L. A.; JUCHEM, S. O.; OVERTON, J. M. Factors affecting conception rate after artificial insemination and pregnancy loss in lactating dairy cows. Animal Reproduction Science, v. 84, n.1, p. 239-255, 2004.

DEJARNETTE, J. M.; LEACH, M. A.; NEBEL, R. L.; MARSHALL, C. E.; MCCLEARY, C. R.; MORENO, J. F. Effects of sex-sorting and sperm dosage on conception rates of Holstein heifers: Is comparable fertility of sex-sorted and conventional semen plausible? Journal of Dairy Science, v. 94. n. 7, p. 3477-3483, 2011.

DEJARNETTE, J. M.; MCCLEARY, C. R.; LEACH, M. A.; MORENO, J. F.; NEBEL, R. L.; MARSHALL, C. E. Effects of 2.1 and $3.5 \times 10^{6}$ sex-sorted sperm dosages on conception rates of Holstein cows and heifers. Journal of Dairy Science, v. 93, n.1, p. 4079-4085, 2010.

DEJARNETTE, J. M.; NEBEL, R. L.; MARSHALL, C. E.; MORENO, J. F.; MCCLEARY, C. R.; LENZ, R. W.. Effect os sex-xorted sperm dosage on conception rates in Holstein heifers and lactating cows. Journal of Dairy Science, v. 91, n. 5, p.1778-1785, 2008. from different bulls reacts differently to the sperm sorting process (Dejarnette et al., 2008; Sales et al., 2011) in a matter that that interpretation of some results may be different when using a different bull (Mallory et al., 2013; Liu et al., 2015). We recognize that the results are restricted to that particular individual when using semen from a single bull.

\section{Conclusion}

It was concluded that artificial insemination of crossbred heifers with sexed and conventional semen between 18 and 24 hours after estrus detection was effective. However, for artificial insemination of crossbred dairy cows, the conception rate for sexed semen was lower than the rate for conventional semen

DEJARNETTE, J. M.; NEBEL, R. L.; MARSHALL, C. E. Evaluating the success of sex-sorted semen in US dairy herds from on farm records. Theriogenology, v. 71. n. 1, p .49-58, 2009.

DOMINGUEZ, J. H.; COSTA, D. S.; CENTURION, V. J.; FARIA, F. $\mathrm{J}$. Pregnancy rate of Nelore females inseminated with male-sexed sêmen. Animal Reproduction Science, v.129, n. 1, p. 127-131, 2011.

GARNER, D. L.; SEIDEL JR, G. E. History of commercializing sexed semen for cattle. Theriogenology, v. 69 , n. 1, p. 886-895, 2008.

HEALY, A. A.; HOUSE, J. K.; THOMSOM P. C. Artificial insemination field data on the use of sexed and conventional semen in nulliparous Holstein heifers Journal of Dairy Science, v. 96, n.1, p. 1905-1914, 2013.

HEINS, B. J.; HANSEN, L. B. Short communication: Fertility, somatic cell score, and production of Normande $\times$ Holstein, Montbéliarde $\times$ Holstein, and Scandinavian Red $\times$ Holstein crossbreds versus pure Holsteins during their first 5 lactations. Journal of Dairy Science, v. 95, n. 2, p. 918-924, 2012.

HEINS, B. J.; HANSEN, L. B.; SEYKORA, A. J. Fertility and survival of pure holsteins versus crossbreds of holstein with normande, montbeliarde, and scandinavian red. Journal of Dairy Science, v. 89, n.1, p. 4944-4951, 2006.

LIU, X.; HU, T.; SUN, W.; HAO, H.; LIU, Y.; ZHAO, X.; DU, W. Comparison of the developmental competence and quality of bovine embryos obtained by in vitro fertilization with sex-sorted and unsorted semen from seven bulls. Livestock Science, v.181, n.1, p. 263-270, 2015.

MALLORY, D. A.; LOCK, S. L.; WOODS, D. C.; POOCK, S. E.; PATTERSON, D. J. Hot topic: Comparison of sex-sorted and conventional semen within a fixed-time artificial insemination protocol designed for dairy heifers. Journal of Dairy Science, v. 96, n. 2, p. 854-856, 2013.

MOCÉ, E.; GRAHAM, J. K.; SCHENK, J. L. Effect of sex-sorting on the ability of fresh and cryopreserved bull sperm to undergo an acrosome reaction. Theriogenology, v. 66, n.1, p. 929-936, 2006.

NORMAN, H. D.; HUTCHISON, J. L.; MILLER, R. H. Use of sexed semen and its effect on conception rate, calf sex, dystocia, and stillbirth of Holsteins in the United States. Journal of Dairy Science, v. 93, n.1, p. 3880-3890, 2010.

OLYNK, N. J.; WOLF, C. A. Expected net present value of pure and mixed sexed semen artificial insemination strategies in dairy heifers. Journal of Dairy Science, v.90, n.1, p. 2569-2576, 2007. 
RENSIS, F. de; SCARAMUZZI, R. J. Heat stress and seasonal effects on reproduction in the dairy cow - a review. Theriogenology, v. 60, n. 6, p.1139-1151,2003.

SÁ FILHO, M. F.; AYRES, H.; FERREIRA, R. M.; NICHI, M.; FOSADO, M.; CAMPOS FILHO, E. P.; BARUSELLI, P. S. Strategies to improve pregnancy per insemination using sexsorted semen in dairy heifers detected in estrus. Theriogenology, v.74, n.1, p.1636-1642, 2010.

SÁ FILHO, M. F.; MENDANHA, M. F.; SALA, R. V.; CARVALHO, F. J.; GUIMARÃES, L. H. C.; BARUSELLI, P. S. Use of sex-sorted sperm in lactating dairy cows upon estrusdetection or following timed artificial insemination. Animal Reproduction Science, v.143,n.1, p.19-23, 2013.

SALES, J. N. S.; NEVES, K. A. L.; SOUZA, A. H.; CREPALDI, G. A.; SALA, R. V.; FOSADO, M.; CAMPOS FILHO, E. P.; FARIA, M.; SÁ FILHO, M. F.; BARUSELLI, P. S. Timing of insemination and fertility in dairy and beef cattle receiving timed artificial insemination using sex-sorted sperm. Theriogenology, v. 76, n. 1, p. 427-435, 2011.

SANGSRITAVONG, S.; COMBS, D. K.; SARTORI, R.; ARMENTANO, L. E.; WILTBANK, M. C. High Feed Intake Increases Liver Blood Flow and Metabolism of Progesterone and Estradiol-17 $\beta$ in Dairy Cattle. Journal of Dairy Science, v.85, n.1, p. 2831-2842, 2002.

SCHAEFFER, L. R.; BURNSIDE, E. B.; GLOVER, P.; FATEHI, $\mathrm{J}$. Crossbreeding results in canadian dairy cattle for production, reproduction and conformation. The Open Agriculture Journal, v. 5, n.1, p. 68-73, 2011.
SCHENK, J. L.; GRAN, D. G.; EVERETT, R. W.; SEIDEL JUNIOR, G. E. Pregnancy rates in heifers and cows with cryopreserved sexed sperm: Effects of sperm numbers per inseminate, sorting pressure and sperm storage before sorting. Theriogenology, v.71, n.1, p.717-728, 2009.

SEIDEL JÚNIOR, G. E.; SCHENK, J. L. Pregnancy rates in cattle with cryopreserved sexed sperm: Effects of sperm numbers per inseminate and site of sperm deposition. Animal Reproduction Science, v.105, n.1, p.129-138, 2008.

SHEHAB-EL-DEEN, M. A. M. M.; LEROY, J. L. M. R.; FADEL, M. S.; SALEH, S. Y. A.; MAES, D.; VAN SOOM, A. Biochemical changes in the follicular fluid of the dominant follicle of high producing dairy cows exposed to heat stress early post-partum. Animal Reproduction Science, v.117, n.1, p.189-200, 2010.

VAZQUEZ, J. M.; PARRILLA, I.; GIL, M. A.; CUELLO, C.; CABALLERO, I.; VAZQUEZ, J. L.; ROCA, J.; MARTÍNEZ, E. A. Improving the efficiency of insemination with sex-sorted spermatozoa. Reproduction in Domestic Animals, v. 43, n. 4, p. 1-8, 2008.

VRIES, A. De; OVERTON, M.; FETROW, J.; LESLIE, K.; EICKER, S.; ROGERS, G. . Exploring the impact of sexed semen on the structure of the dairy industry. Journal of Dairy Science, v. 91, n.1, p. 847-856, 2008.

WALSH, S. W.; WILLIAMS, E. J.; EVANS, A. C. O. A review of the causes of poor fertility in high milk producing dairy cows. Animal Reproduction Science, v.123, n.1, p.127-138, 2011.

WEIGEL, K. A. Exploring the role of sexed semen in dairy production systems. Journal of Dairy Science, v. 87, n. 1, p. 120130, 2004 